Alaska Division of Geological \& Geophysical Surveys

MISCELLANEOUS PUBLICATION 139

\title{
TECHNICAL REVIEW OF A TRENCH ACROSS A POTENTIAL FAULT SCARP FEATURE EAST OF LOWER TALARIK CREEK, LAKE ILIAMNA AREA, SOUTHWESTERN ALASKA
}

\author{
by \\ Rich D. Koehler
}

November 2010

\author{
Released by \\ STATE OF ALASKA \\ DEPARTMENT OF NATURAL RESOURCES \\ Division of Geological \& Geophysical Surveys \\ 3354 College Rd. \\ Fairbanks, Alaska 99709-3707
}

$\$ 2.00$ 



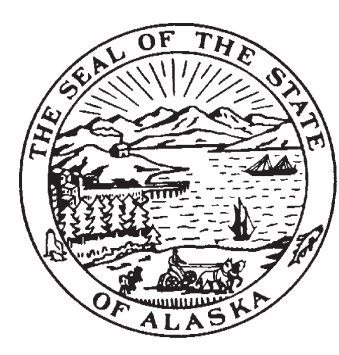

DIVISION OF GEOLOGICAL \& GEOPHYSICAL SURVEYS

Robert F. Swenson, State Geologist and Director

Publications produced by the Division of Geological \& Geophysical Surveys can be examined at the following locations. To order publications, contact the Fairbanks office.

\author{
Alaska Division of Geological \& Geophysical Surveys \\ 3354 College Rd., Fairbanks, Alaska 99709-3707 \\ Phone: (907) 451-5020 Fax (907) 451-5050 \\ dggspubs@alaska.gov \\ www.dggs.alaska.gov
}

Alaska State Library

State Office Building, 8th Floor

3354 College Road

Juneau, Alaska 99811-0571

Elmer E. Rasmuson Library University of Alaska Fairbanks Fairbanks, Alaska 99775-1005
Alaska Resource Library \& Information Services (ARLIS)

3150 C Street, Suite 100

Anchorage, Alaska 99503

University of Alaska Anchorage Library 3211 Providence Drive

Anchorage, Alaska 99508 



\title{
TECHNICAL REVIEW OF A TRENCH ACROSS A POTENTIAL FAULT SCARP FEATURE EAST OF LOWER TALARIK CREEK, LAKE ILIAMNA AREA, SOUTHWESTERN ALASKA
}

\author{
by \\ Rich D. Koehler ${ }^{1}$
}

\section{INTRODUCTION}

The State of Alaska, Division of Geological \& Geophysical Surveys (DGGS) conducted a technical field review of a trench excavation across a surficial scarp feature east of Lower Talarik Creek in the Lake Iliamna area of southwestern Alaska (fig. 1). The purpose of the field review was to assess the origin of the surficial scarp and to evaluate the trench exposure for the presence or absence of features indicative of active faulting. The review was performed July 11-12, 2010, at the request of Bretwood Higman of Ground Truth Trekking, who excavated the trench. The scarp feature lies approximately $5.6 \mathrm{~km}$ (3.5 mi) north of the modern shoreline of Lake Iliamna at GPS coordinates $59.67946^{\circ} \mathrm{N},-155.4121^{\circ} \mathrm{W}$ (fig. 1). The feature is along strike and has an orientation similar to the topographic valley of Lake Clark and the Lake Clark fault.

The Lake Clark fault extends from Cook Inlet southwest through the Alaska Range to the vicinity of Lake Clark. However, the fault has not been mapped west of the lake (Detterman and Reed, 1980). Previous studies on the Lake Clark fault have shown 500-1,000 m (1,640-3,280 ft) northwest-side-up vertical displacement (Detterman and others, 1976). Estimates of post-Eocene right lateral displacements range from 5-26 km ( 3-16 mi) (Haeussler and Saltus, 2005; Plafker and others, 1975). The Neotectonic Map of Alaska classifies the Lake Clark fault as "Neogene" with evidence of late Cenozoic displacement (Plafker and others, 1994). In addition to uncertainties in the location of the fault, other essential parameters for seismic hazards assessment including timing and rate of Quaternary deformation, elapsed time since the last event, and displacement per event have not been previously documented for the Lake Clark fault. The fault has the potential to affect the engineering design of a proposed renewable-energy power plant(s) at Mt. Spurr and/or Lake Chakachamna, as well as the proposed Pebble coppergold mineral project north of Lake Iliamna. Thus, field evaluation aimed at understanding the seismic potential of the Lake Clark fault has implications for resource development and seismic hazards assessments for the region.

\section{IN PERFORMING THE REVIEW, DGGS:}

1. Reviewed and assessed images and descriptions of the scarp feature obtained from the Ground Truth Trekking website (http://www.groundtruthtrekking.org/);

2. Conducted limited geological analysis such as map review and aerial photograph interpretation to assess geological conditions at the site;

3. Reviewed previous bedrock and Quaternary surficial-geologic maps covering the site area (Detterman and Reed, 1980; Detterman and Reed, 1973);

4. Completed a site visit to visually inspect the excavation and record observations; and

5. Prepared this summary report.

At the time of the site review, a level line grid had not been established on the trench wall and stratigraphic units had not been flagged. Thus, a separate log of the exposure was not drawn.

\section{SUMMARY OF FINDINGS}

\section{LITERATURE REVIEW AND AERIAL AND GROUND OBSERVATIONS}

The majority of the surficial materials and present topography in the Iliamna Quadrangle are related to late Wisconsin glaciations including moraines and associated deposits of the Kvichak, Iliamna, Newhalen, and Iliuk stades (Detterman and Reed, 1973). In the vicinity of the scarp feature, these deposits include outwash plains, moraines, kettle lakes, and shorelines of former highstands of Lake Iliamna, among others (fig. 2). The scarp feature extends across deposits interpreted by Detterman and Reed (1973) to be hanging delta and outwash fan

${ }^{1}$ Alaska Division of Geological \& Geophysical Surveys, 3354 College Rd., Fairbanks, Alaska 99709-3707; rich.koehler@alaska.gov 


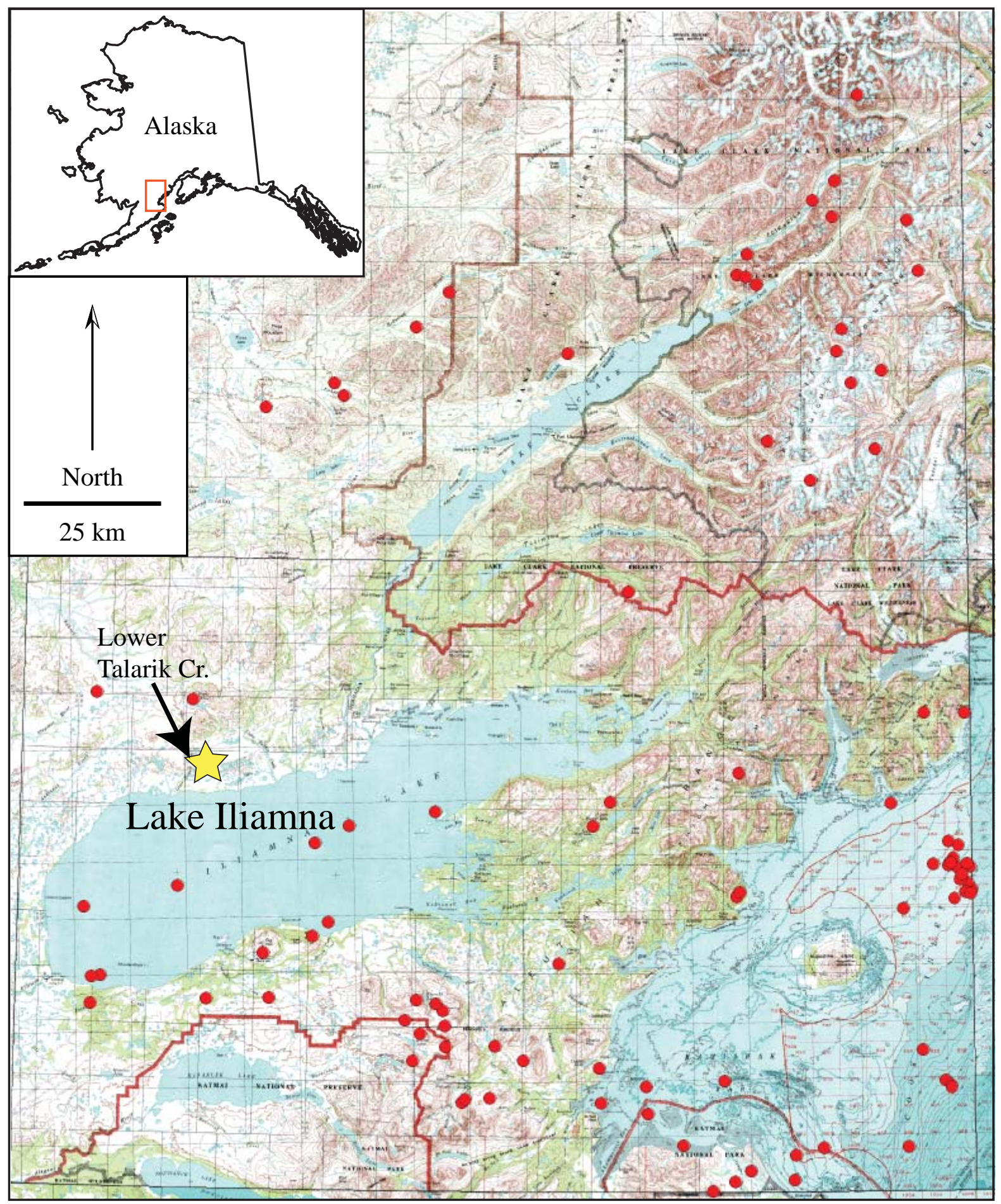

Figure 1. Location map of scarp feature east of Lower Talarik Creek and north of Lake Iliamna. General location of scarp feature is indicated by yellow star. Location shown in greater detail on the air photo in figure 2. Red circles are earthquakes greater than magnitude $M L=2.0$ with depths between 2 and $15 \mathrm{~km}$ (1.2 and $9.3 \mathrm{mi})$ recorded between 1968 and 2010. Deeper earthquakes related to Aleutian subduction zone are not shown. The location accuracy of the epicenters is poorly constrained due to changes in the network over time. Data source: Alaska Earthquake Information Center. Inset shows State of Alaska for reference; red box indicates general vicinity of the map. 


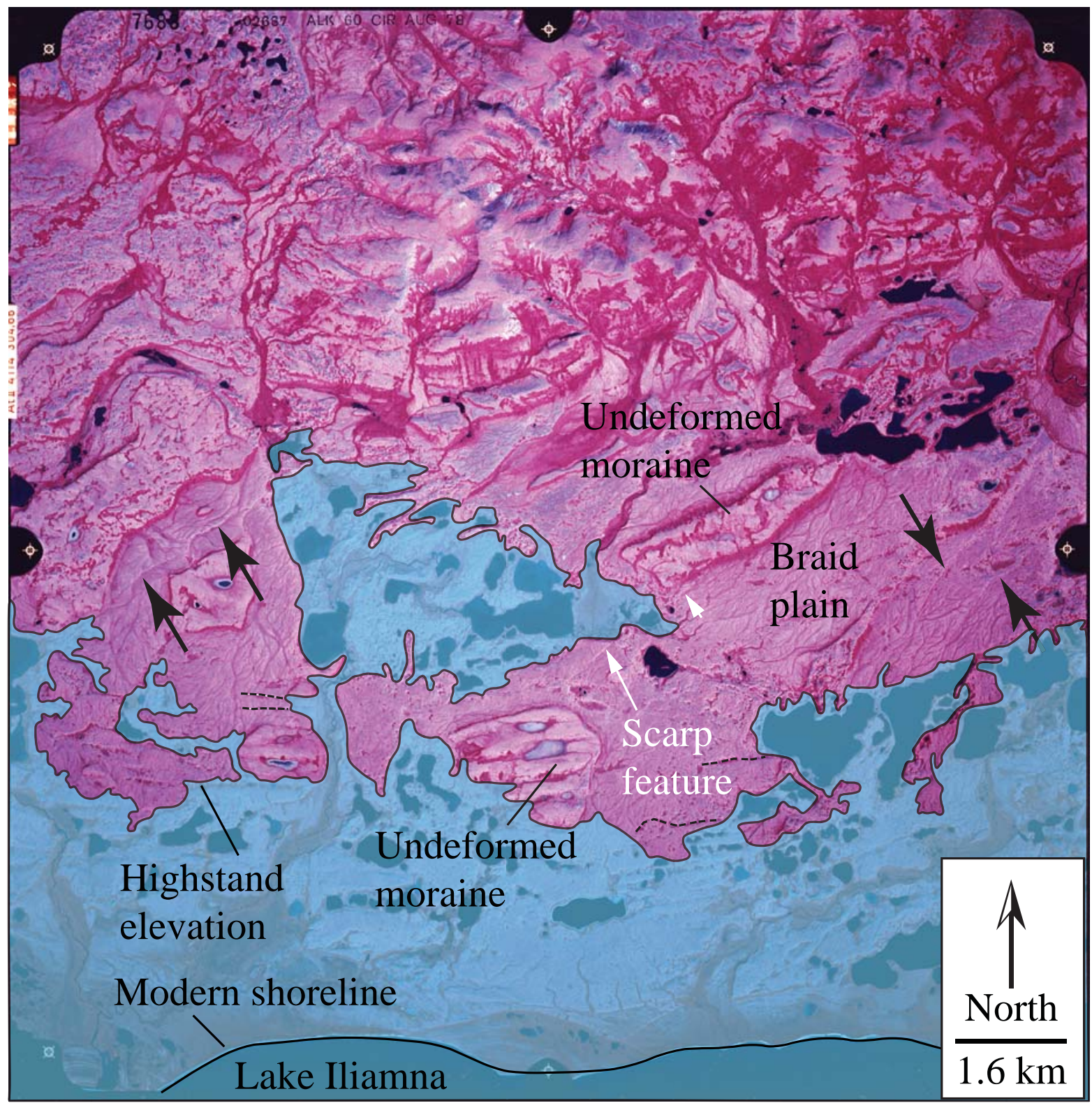

Figure 2. Color infrared air photo showing geomorphic features near the scarp feature. Similar scarp features exist both to the northwest and southeast of the site and are shown by black arrows. Approximate outline of the highstand of Lake Iliamna during late Wisconsin time is shown. Highstand elevation is based on comments in Detterman and Reed (1973) indicating that it was 46 m (150 ft) above present lake level. Thus, highstand is shown as a line at the $61 \mathrm{~m}$ (200 ft) contour interpreted from the Iliamna C-7, 1:63,360-scale topographic quadrangle. Dashed black lines mark shoreline features that may indicate that the highstand was higher than shown in some places. 
deposits (Qdf) (fig. 3). Prominent shoreline features related to the highest lake level can be identified in air photos and occur at an elevation of approximately $46 \mathrm{~m}$ (150 ft) higher than the present lake level, or around $61 \mathrm{~m}$ (200 $\mathrm{ft}$ ) (Detterman and Reed, 1973). Figure 2 shows an interpretation of where the landscape was covered by the highstand lake, based on paleo-shorelines and the $61 \mathrm{~m}$ (200 ft) contour line on the Iliamna C-7, 1:63,000-scale quadrangle. The scarp feature is close to the elevation of the highstand lake. From the air, the scarp is a southeastfacing slope characterized by distinct light yellow vegetation (fig. 4). The surface on the northwestern side of the scarp is characterized by gentle swales marked by darker vegetation consistent with drainage to the northwest. The surface to the southeast of the scarp is characterized by subtle bar and swale morphology consistent with drainage parallel to the scarp (southwest).

The $\sim 1$-m-high ( 3-ft-high) scarp is continuous for about $2.5 \mathrm{~km}(1.6 \mathrm{mi})$ and extends southwest-northeast between two prominent terraced and modified moraine deposits (Qbm; Detterman and Reed, 1973) along a broad braid plain characterized by anastomosing channels (fig. 2). Depressions and kettle lakes related to glacial ice stagnation and melting are common on the braid plain surface. The crest and base of the scarp are rounded and the slope is gentle. Northeast of the trench, the scarp bisects and projects across a circular-shaped kettle depression that is undeformed (fig. 4). At the southwestern extent of the feature, it bends to a more westerly orientation and becomes less distinct (fig. 2). Scarps do not appear in the moraine deposits in either direction along strike of the scarp feature and their margins are not offset.

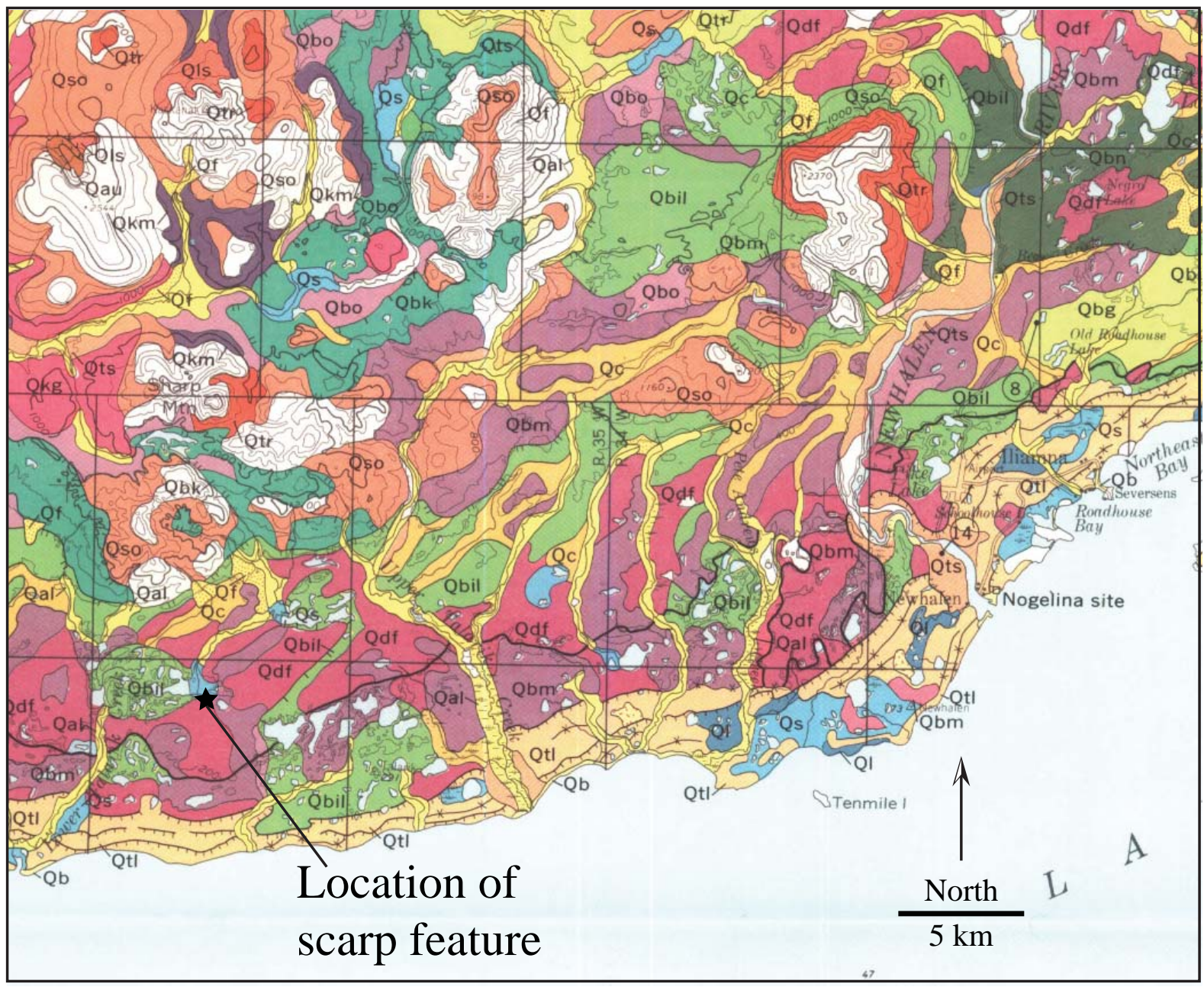

Figure 3. Quaternary geologic map of the project vicinity (Detterman and Reed, 1973). Quaternary stratigraphic units in the vicinity of the scarp feature include: Qbm, terraced and modified morainal deposits; Qbil, moraine of Iliamna stade; Qdf, hanging delta and outwash fan deposits; and Qtl, lake terrace and beach ridge deposits. The location of the scarp feature is mapped as hanging delta and outwash fan deposits and is shown by a black star. 


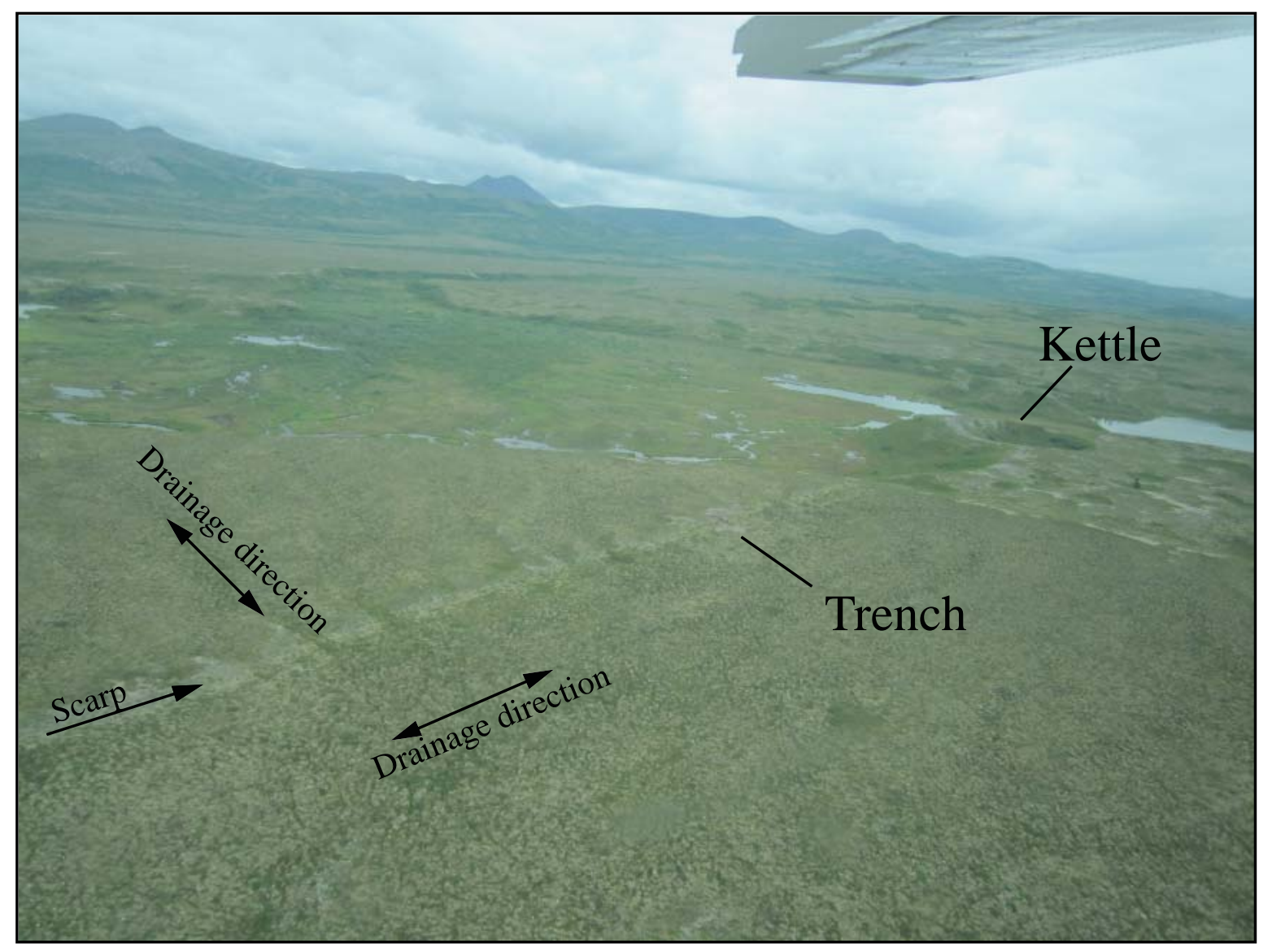

Figure 4. Photograph of the trench site from fixed-wing aircraft; view is toward the north. Scarp is indicated by an arrow. Location of trench excavation is shown. Note that the scarp feature projects across a circular-shaped kettle depression that is not deformed (upper right).

\section{TRENCH EXCAVATION OBSERVATIONS}

The trench was hand excavated by Higman prior to my arrival, across an approximately 1-m-high (3-ft-high) gently sloping scarp feature, and was about $8 \mathrm{~m}(26 \mathrm{ft})$ long and $2.5 \mathrm{~m}(8 \mathrm{ft})$ deep. Stratigraphy exposed in the wall consisted of a package of interbedded sand, gravel, and cobbles overlain by a loess layer (fig. 5). Individual beds range from between 5 and $15 \mathrm{~cm}$ (2 and 6 in) in thickness and are characterized by wavy basal contacts. Clast-supported beds typically consist of rounded to subrounded cobbles averaging around $5 \mathrm{~cm}$ (2 in) diameter, and gravel. Matrix-supported beds are sandy gravel with trace cobbles. Continuous beds can be mapped across the lower part of the exposure to where they intersect the sloping floor of the trench. Deposits in the northwestern part of the trench dip southeast, and appear to flatten beneath the central part of the scarp (fig. 5A). Facies changes are common and some beds are discontinuous; however, subtle thin beds can be traced continuously across the central part of the scarp. In the central upper part of the exposure, the stratigraphy is characterized by a swale that may indicate deposition in a channel (white dashed line on fig. 5B). The stratigraphic package is capped by a loess deposit that thickens over the scarp. Bioturbation and possibly cryoturbation processes have entrained trace cobbles and gravel in the loess.

The stratigraphy exposed in the trench is coherent to the surface and continuous across the exposure. No evidence was observed that would support the existence of distinct fault planes, shear zones, or vertically or horizontally displaced deposits. In particular, there are no vertical separations in the stratigraphy that match the surface scarp height. Additionally, colluvial deposits are not present at the base of the scarp. Instead, thinly bedded fluvial deposits are present up to the base of the soil. 

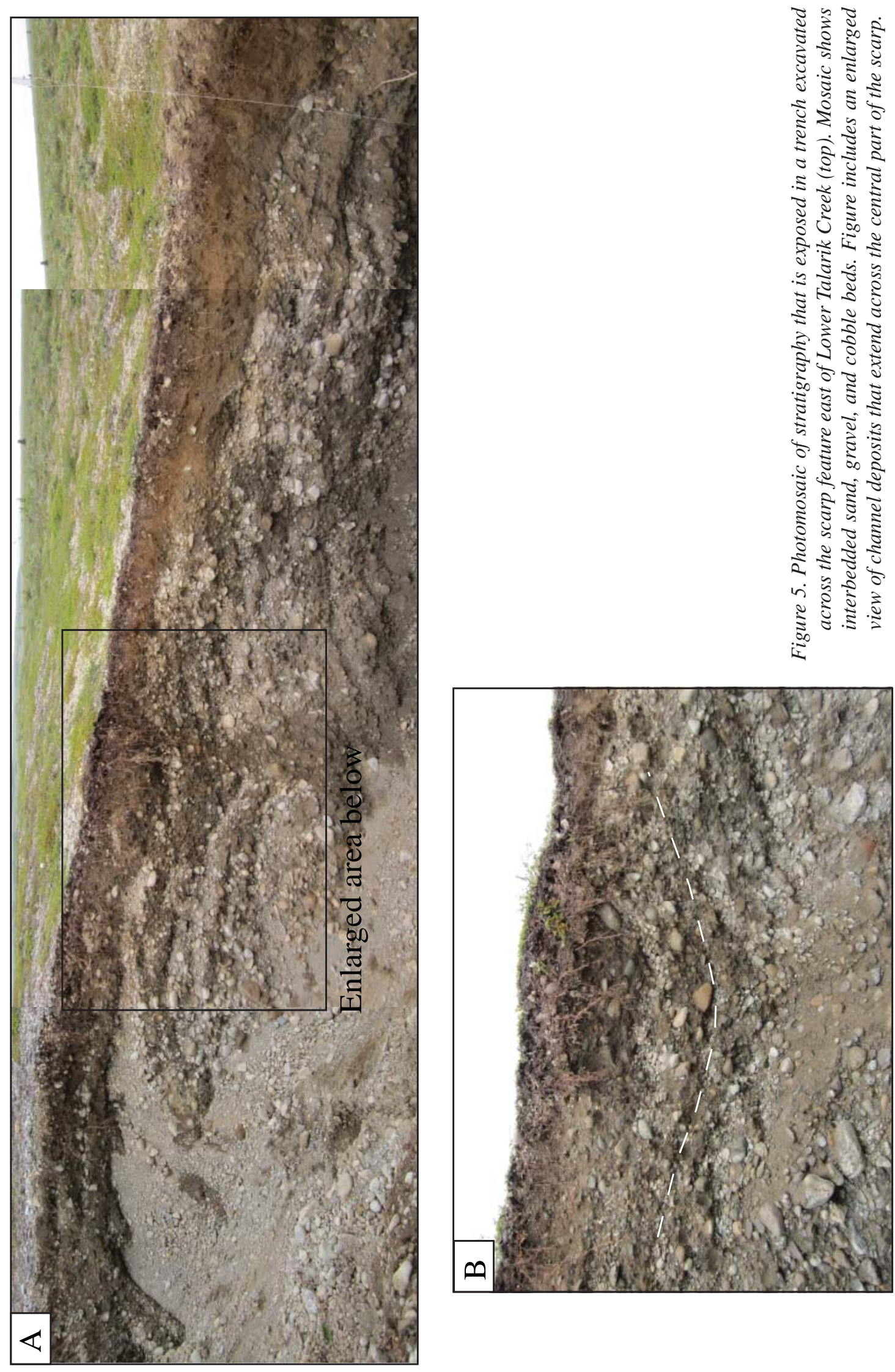


\section{DISCUSSION}

The Lake Clark fault has not previously been recognized west of Lake Clark despite numerous attempts by various workers (Detterman and Reed, 1980; Detterman and Reed, 1973; Plafker and others, 1975). Plafker and others (1975) performed aerial and limited field reconnaissance along the entire length of the fault and determined that there is no evidence along the fault trace of offset topographic features or glacial deposits suggestive of Quaternary displacement. Given the relatively unvegetated, subdued glacial topography west of Lake Clark, any active fault traces should be easily observed, however, none have been identified to date. The scarp feature investigated in this review is apparently the first subsurface study of a potentially tectonic lineament west of Lake Clark.

On the basis of surface and subsurface stratigraphic observations obtained during this review, a non-tectonic origin for the scarp feature best fits the available information. Direct evidence in support of the absence of faulting includes unbroken stratigraphy observed in the trench that is continuous in the subsurface across the scarp. Indirect evidence for a non-tectonic origin includes the lack of faults and shear planes, generally flat-lying stratigraphy, lack of scarp-derived colluvial deposits, and absence of stratigraphic displacements. Several other linear features occur to the west and east of the scarp feature (black arrows on fig. 2). These features have similar linearity and surficial characteristics on air photos, but have different orientations. The existence of these features provides additional support that they were not formed by tectonic movements on a discrete fault, but are more consistent with a regional erosional event. The apparent thickening of loess across the scarp could be related to wetter conditions in the channel at the base of the scarp that would be favorable for loess accumulation. Alternatively, the loess may have been deflated off the upper part of the scarp as documented elsewhere (Boothroyd and Nummedal, 1978) and accumulated on the lee side of the scarp.

Historical seismicity for the period 1968 to 2010 for earthquakes less than $15 \mathrm{~km}$ (9.3 mi) depth and greater than magnitude 2 is shown on figure 1 . Seismicity is noticeably absent from the trough of Lake Clark as well as the region around the scarp feature. In a worldwide dataset of 421 earthquakes, very few events with surface rupture lengths less than $5 \mathrm{~km}$ (3.1 mi) produced surface displacements greater than about $20 \mathrm{~cm}$ (7.9 in) (table 1 in Wells and Coppersmith, 1994). Additionally, Wells and Coppersmith (1994) showed that surface rupture lengths of between 9 and $100 \mathrm{~km}$ (5.5 and $62 \mathrm{mi}$ ) were necessary to produce surface displacements of $\sim 1 \mathrm{~m}$ ( $\sim 3$ $\mathrm{ft})$, similar to the height of the scarp feature at the site. Thus, the height $(\sim 1 \mathrm{~m}[\sim 3 \mathrm{ft}])$ and length $(2.5-3 \mathrm{~km}[1.5-2$ $\mathrm{mi}]$ ) of the scarp are not consistent with the available dataset of worldwide surface ruptures. All of the deposits in the site vicinity are of the same relative age (late Wisconsin), and therefore a tectonic scarp should cut all of the deposits. The lack of continuity of the scarp and the occurrence of undeformed moraine landforms along strike to the northeast and southwest provide additional support for a nontectonic origin for the scarp.

The temporal variations in depositional environment related to advances and retreats of four late Wisconsin glaciations preclude an unequivocal assessment of the origin of the scarp. However, a cursory look into the proglacial and pluvial lake literature (Ritter and others, 2002), and in particular, braid plain (Smith, 1985) and lake marginal (Adams and Wesnousky, 1998) sedimentology and geomorphology, indicates many processes that are capable of forming the subtle localized scarp observed at the site. As the various glacial stades advanced and retreated, the site of the scarp alternated between ice proximal, intermediate, and ice distal environments. The presence of kettles and moraines adjacent to the scarp and a broad, gently sloping plain with shallow, anastomosing channels is consistent with ice stagnation in the ice proximal environment (Price 1969; 1973) followed by glaciofluvial deposition more distal from the glacier (Ritter and others, 2002). The elevation of the late Wisconsin highstand shoreline of pluvial Lake Iliamna is close to the scarp feature indicating that at least for a period of time the site was in a lake-marginal environment. Geomorphic features typical of lake-marginal environments are shown on figure 6. Possible existence of beach bars, sand spits, and shorelines may have influenced the distribution of glaciofluvial sediments entering the lake.

In modern glaciofluvial outwash plains, the intermediate zone is characterized by lateral channel migration across the braid plain that leaves a maze of abandoned channels with relief of 1-2 m (3-6.5 ft). Channels typically have gentle side slopes, high width/depth ratios, and low sinuosities. Aggradation takes place during high flow events and can be associated with rapid formation and destruction of small bars (Smith, 1985; Southard and others, 1984). In the distal zone, braid plains become shallower and poorly defined and flow may merge into a single sheet during high discharge. Individual glacial advances develop their own outwash plains, the surfaces of which are generally located at different elevations (Smith, 1985).

The general geomorphic characteristics of glaciofluvial outwash plains are consistent with the surficial observations at the scarp feature investigated during this review. In particular, gentle sloping channel margins, anastomosing channels, inset surfaces, and proximity to late Wisconsin glaciers are consistent with a glaciofluvial origin for the 


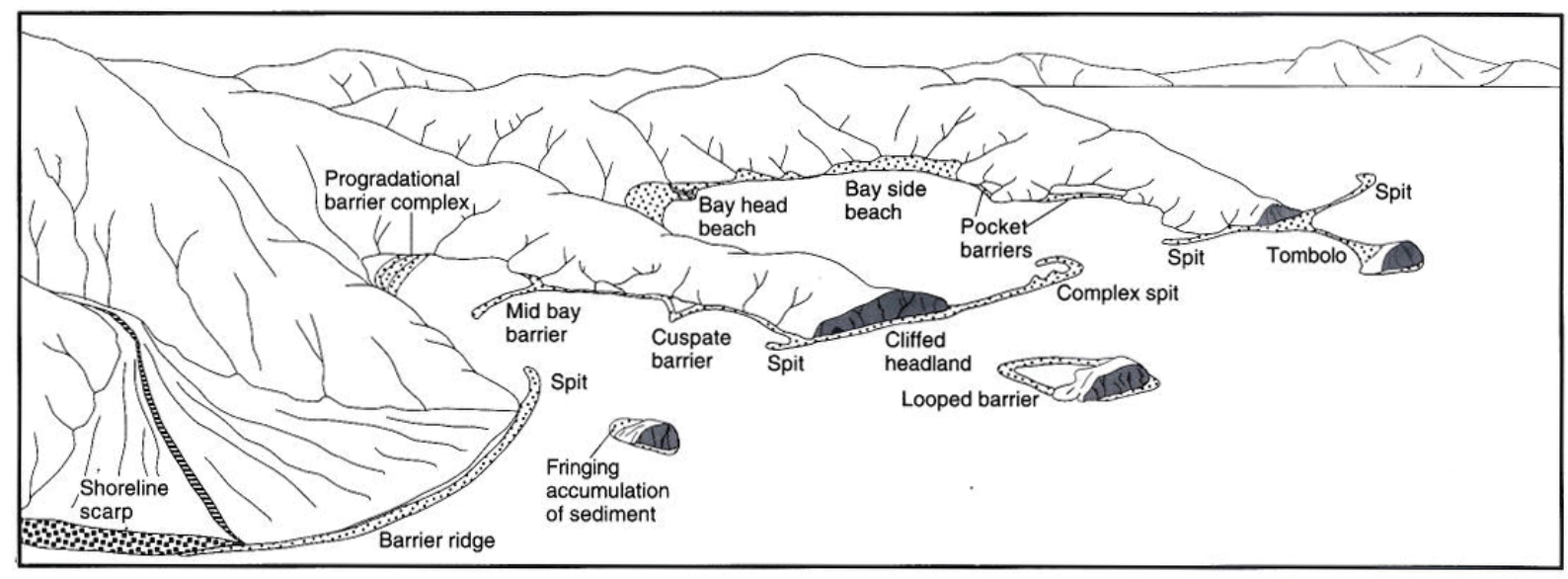

Figure 6. Depositional landforms associated with pluvial lakes in Nevada during the latest Wisconsin highstand (Adams and Wesnousky, 1998). The topography in Nevada is steeper than the topography near the scarp feature investigated during this review. However, similar lake-marginal landforms likely formed in the vicinity of the highstand of Lake Iliamna. Many of these landforms may have been modified by outwash channels related to subsequent glaciations.

scarp. Figure 7A shows these types of features on a modern glaciofluvial outwash plain. As evident in the photo in figure 7A, several channels have linear margins and truncate previous channels similar to what is observed at the scarp site. In addition to the surface observations, the sedimentological characteristics of the deposits observed in the trench are also consistent with a glaciofluvial origin. Figure 7B shows outwash plain sediments exposed on the Kicking Horse River in British Columbia, which are similar to the deposits in the trench (fig. 5). At both locations, the stratigraphy consists of alternating thin layers of matrix-supported and open-work gravels. Thus, based on surficial and subsurface observations, previous mapping, and characteristics of braid plains described above, the site is interpreted as a braid plain transitioning to a fan delta that deposited into paleo Lake Iliamna at its late Wisconsin highstand. Subsequent glaciations and their associated glaciofluvial outwash plains may have further modified the site.

The lack of scarp-derived colluvium(s) in the trench suggests that the scarp did not originate as a vertical free face and provides additional support for formation as a gentle channel margin along a shallow braided stream. As shown on figure 4, distributary channels draining northwest across the surface above the scarp are truncated by southwest-trending distributary channels cut into the inset surface below the scarp. Thus, the surface stratigraphic relation suggests that the scarp was formed by incision of the lower braid plain into the older, higher braid plain. Sufficient data is not available to evaluate the timing of the incision; however, similar surficial characteristics suggest that the two surfaces are of similar relative age. The lower surface may have been cut as the delta graded to a subsequent (but lower) paleo lake highstand related to one of the younger glacial stades. Alternatively, the incision could have occurred rapidly in response to variations in seasonal flow, sediment load, and deposition.

\section{CONCLUSION}

This field review focused on a surficial scarp east of Lower Talarik Creek north of Lake Iliamna. Surface geomorphic relations and inspection of a trench excavation across the scarp are the primary data used to assess the presence or absence of features indicative of tectonic activity. The site location was repeatedly glaciated during late Wisconsin glacial advances and Quaternary deposits are all of glacial origin. The scarp feature is not associated with seismicity and is not continuous. The stratigraphy in the trench is unbroken and has physical characteristics consistent with a glaciofluvial origin. Thus, it is the conclusion of this review that the scarp feature is remnant of successive outwash plain erosion and deposition, and not a scarp related to movement on the Lake Clark or other fault. The existence or location of the Lake Clark fault west of Lake Clark remains unknown. 

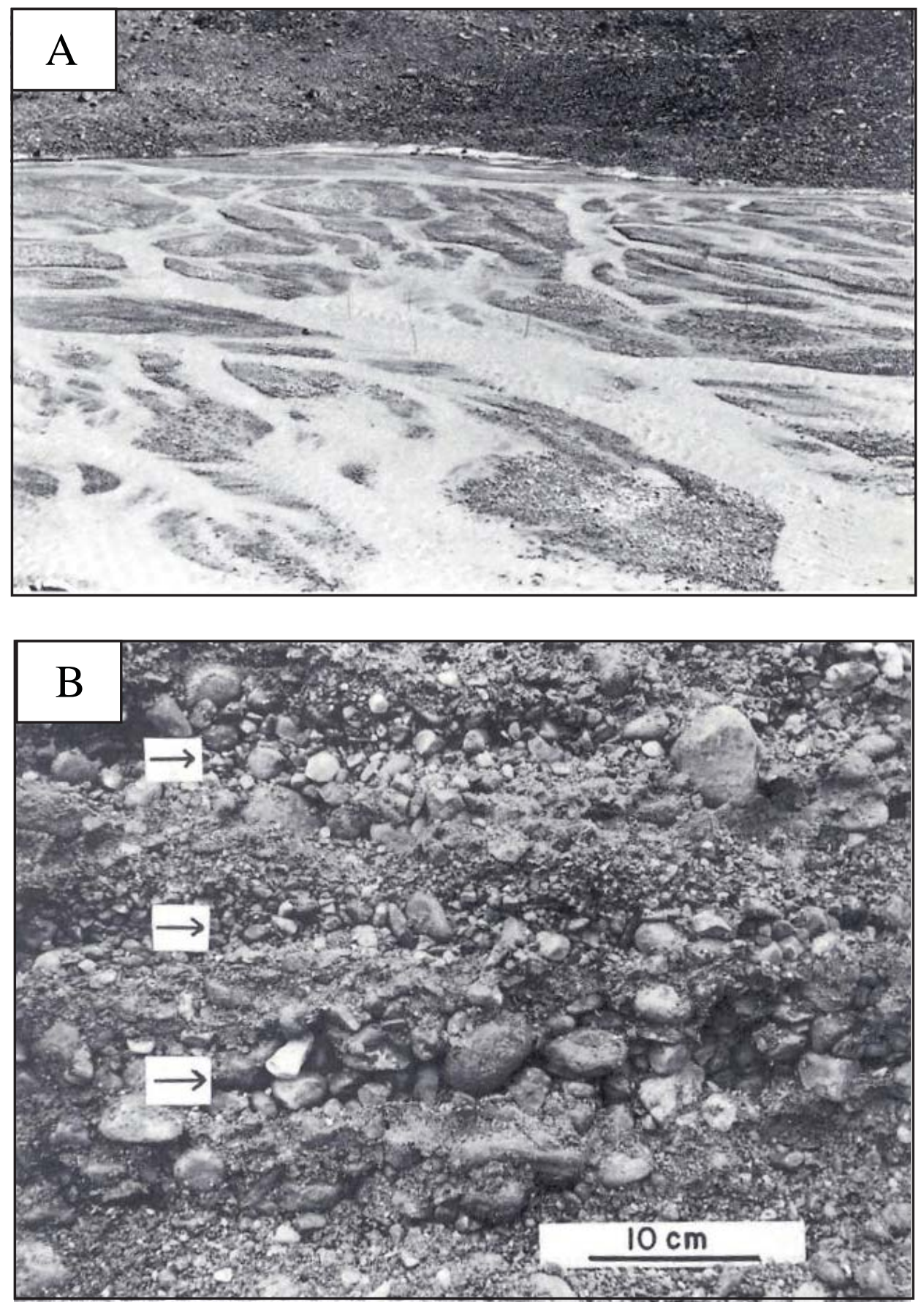

Figure 7. (A) Glacial outwash braid plain of Hilda Glacier, Alberta, showing gently sloping channel margins. (B) Stratigraphy along the Kicking Horse River, British Columbia, showing typical outwash braid plain deposits consisting of alternating layers of matrix-supported and clast-supported gravels. Fines transported in high flow settle into interstitial spaces as flows subside, eventually clogging pore spaces in the upper part of some layers. Arrows point to clast-supported layers. Both photos from Smith (1985). 


\section{ACKNOWLEDGMENTS}

Site review and travel were funded by the State of Alaska. Review of the report by State Geologist Bob Swenson and Deputy Director Rod Combellick at the Division of Geological \& Geophysical Surveys is appreciated. Gratitude is extended to Bretwood Higman and the field crew for the opportunity to visit the site and for assistance with travel logistics.

\section{REFERENCES}

Adams, K.D., and Wesnousky, S.G., 1998, Shoreline processes and the age of the Lake Lahontan highstand in the Jessup embayment, Nevada: Geological Society of America Bulletin, v. 110, no. 10, p. 1,318-1,332.

Boothroyd, J.C., and Nummedal, Dag, 1978, Proglacial braided outwash: A model for humid alluvial fan deposits, in Miall, A.D., ed., Fluvial Sedimentology: Canadian Society of Petroleum Geology, Memoir 5, p. 641-668.

Detterman, R.L. and Reed, B.L., 1973, Surficial deposits of the Iliamna quadrangle, Alaska: U.S. Geological Survey Bulletin 1368-A, p. A1-A64, 1 sheet, scale 1:250,000.

1980, Stratigraphy, structure, and economic geology of the Iliamna quadrangle, Alaska: U.S. Geological Survey Bulletin 1368-B, p. B1-B86, 1 sheet, scale 1:250,000.

Detterman, R.L., Hudson, Travis, Plafker, George, Tysdal, R.G., and Hoare, J.M., 1976, Reconnaissance geologic map along the Bruin Bay and Lake Clark faults in Kenai and Tyonek quadrangles, Alaska: U.S. Geological Survey Open-File Map 76-477, 4 p., scale: 1:250,000.

Haeussler, P.J., and Saltus, R.W., 2005, 26 km of offset on the Lake Clark fault since late Eocene time: U.S. Geological Survey Professional Paper 1709-A, 4 p., http://pubs.usgs.gov/pp/pp1709a/.

Plafker, George, Detterman, R.L., and Hudson, Travis, 1975, New data on the displacement history of the Lake Clark fault, in Yount, M.E., ed., United States Geological Survey Alaska Program, 1975: U.S. Geological Survey Circular 722, p. 44-45.

Plafker, George, Gilpin, L.M., and Lahr, J.C., 1994, The Neotectonic map of Alaska, in the Geology of Alaska, v. G-1, The Geology of North America: Boulder, CO, Geological Society of America, plate 12.

Price, R.J., 1969, Moraines, sandar, kames, and eskers near Breidamerkurjoekull, Iceland: London, Transactions, Institute of British Geographers, no. 46, p. 17-42.

1973, Glacial and fluvioglacial landforms: New York, Hafner Publishing Co., 242 p.

Ritter, D.F., Kochel, R.C., and Miller, J.R., 2002, Process Geomorphology, Fourth edition: Long Grove, Illinois, Waveland Press, Inc., 560 p.

Smith, N.D., 1985, Chapter 3, Proglacial fluvial environment, in Ashley, G.M., Shaw, John, and Smith, N.D., eds., Glacial sedimentary environments: Society of Economic Paleontologists and Mineralogists, SEPM Short Course No. 16., p. 85-134.

Southard, J.B., Smith, N.D., and Kuhnle, R.A., 1984, Chutes and lobes: Newly identified elements of braiding in shallow gravelly streams, in Koster, E.H., and Steel, R.J., eds., Sedimentology of gravels and conglomerates: Canadian Society of Petroleum Geology, Memoir 10, p. 51-59.

Wells, D.L., and Coppersmith, K.J., 1994, New empirical relationships among magnitude, rupture length, rupture width, rupture area, and surface displacement: Bulletin of the Seismological Society of America, v., 84, no. 4, p. $974-1,002$. 